\title{
Physicochemical characterization and in vitro evaluation of the antioxidant and anticandidal activities of Moroccan propolis
}

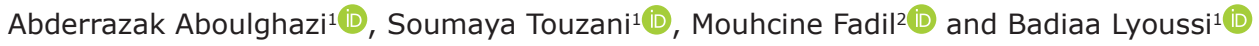 \\ 1. Department of Biology, Laboratory of Natural Substances, Pharmacology, Environment, Modeling, Health, and \\ Quality of Life (SNAMOPEQ), Faculty of Sciences Dhar Mehraz, Sidi Mohamed Ben Abdellah University, Fez 30000, \\ Morocco; 2. Physicochemical Laboratory of Inorganic and Organic Materials, Materials Science Center, Mohammed V \\ University in Rabat, Morocco. \\ Corresponding author: Badiaa Lyoussi, e-mail: lyoussi@gmail.com \\ Co-authors: AA: abdouaboughazi1@gmail.com, ST: touzani.soumaya@gmail.com, MF: fadil.mouhcine@gmail.com \\ Received: 23-08-2021, Accepted: 13-01-2022, Published online: 15-02-2022
}

doi: www.doi.org/10.14202/vetworld.2022.341-349 How to cite this article: Aboulghazi A, Touzani S, Fadil M, Lyoussi B (2022) Physicochemical characterization and in vitro evaluation of the antioxidant and anticandidal activities of Moroccan propolis, Veterinary World, 15(2): 341-349.

\begin{abstract}
Background and Aim: Human mycotic infections are one of the major health problems worldwide. Prolonged use of antimycotic drugs has contributed to the development of resistance in pathogenic fungi. This study was conducted to examine antioxidant and anticandidal activities of Moroccan propolis.
\end{abstract}

\begin{abstract}
Materials and Methods: Two ethanolic extracts of Moroccan propolis from the Fez-Meknes region were evaluated regarding the following physicochemical parameters: Yield, $\mathrm{pH}$, total carbohydrates, total proteins, total lipids, minerals, total phenolic content, total flavonoid content, and antioxidant activity using ferric reducing antioxidant power (FRAP) and 2,2'-azino-bis (3-ethylbenzothiazoline-6-sulfonic acid) (ABTS) assays. In addition, we assessed the in vitro anticandidal activity against vulvovaginal candidiasis strains, that is, Candida albicans, Candida glabrata, Candida parapsilosis, and Candida krusei, using the broth micromethod according to the CLSI/M27-A3 reference guidelines.
\end{abstract}

Results: The propolis samples exhibited a mean yield of $16 \%$, with an acidic $\mathrm{pH}$ ranging from 4.8 to 5.9 ; the sample from the Oued Amlil area (OAPEE) contained high levels of resin, balsam, moisture, total carbohydrates, and total lipids: $59.8 \%$, $0.71 \%, 2 \%, 1.01 \mathrm{gGlcEq} / \mathrm{g}$, and $120 \mathrm{mg} / \mathrm{g}$, respectively. Moreover, the sample from the Sefrou area (SFPEE) was richer in total proteins and minerals, with values of $2.5 \mathrm{~g} / 100 \mathrm{~g}$ and $1.84 \%$, respectively. The total polyphenol and flavonoid content in the propolis extracts were 117.38 and $194.68 \mathrm{mg}$ of gallic acid equivalent/g, and $17.45-27.79 \mathrm{mg}$ of quercetin equivalent/g, respectively. Regarding the antioxidant activity, the most effective propolis extract was the sample from the Sefrou area, at $72.5 \mu \mathrm{g} / \mathrm{mL}$ and $118.78 \mu \mathrm{moL} \mathrm{Fe}{ }^{2+} / \mathrm{g}$ for ABTS-half-maximal inhibitory concentration and FRAP-half maximal effective concentration, respectively. The analysis of phenolic compounds using high-performance liquid chromatography with a diode-array detector revealed the presence of 13 polyphenols. The main compound in the OAPEE sample was epicatechin $(310 \mathrm{mg} / \mathrm{g})$, whereas in the SFPEE sample was apigenin $(410 \mathrm{mg} / \mathrm{g})$. Regarding the antifungal activity against Candida species, the minimum inhibitory concentration and minimum fungicidal concentration of the Moroccan propolis ethanolic extracts ranged between 31.2 and $62.5 \mu \mathrm{g} / \mathrm{mL}$ and 62.5 and $125 \mu \mathrm{g} / \mathrm{mL}$, respectively, comparable with fluconazole (as a reference antimycotic).

Conclusion: This study suggests that Moroccan propolis (31.2 and $125 \mu \mathrm{g} / \mathrm{mL}$ ) may be an important source of bioactive molecules with anticandidal activity. Propolis may be a promising naturally-occurring candidate for the development of antimycotic drugs.

Keywords: antioxidant activity, propolis, total flavonoids, total polyphenols, vulvovaginal candidiasis.

\section{Introduction}

About $75 \%$ of women with sexual activity have at least one episode of mycotic infection over their lifespan [1]. Mycotic infections are the most common reason for gynecology consultation [2], are caused by the commensal and saprophytic yeast Candida. This microorganism may, in some situations, become a pathogen causing local infections, that is,

Copyright: Aboulghazi, et al. Open Access. This article is distributed under the terms of the Creative Commons Attribution 4.0 International License (http://creativecommons.org/licenses/ by/4.0/), which permits unrestricted use, distribution, and reproduction in any medium, provided you give appropriate credit to the original author(s) and the source, provide a link to the Creative Commons license, and indicate if changes were made. The Creative Commons Public Domain Dedication waiver (http:// creativecommons.org/publicdomain/zero/1.0/) applies to the data made available in this article, unless otherwise stated. vulvovaginal candidiasis [3]. Although Candida albicans remains the species that are isolated most often during these infections, a considerable increase in the frequency of non-C. albicans species has also been highlighted, mainly Candida glabrata, which is isolated in $5-15 \%$ of cases of vulvovaginal candidiasis, as well as Candida parapsilosis, Candida tropicalis, and Candida krusei [4]. In recent years, antifungal resistance has become an increasing problem associated with the fungus Candida, and the optimization of therapies for candidiasis has been the focus of broad research. Moreover, the antifungal drugs available for the treatment of candidiasis infections are quite restricted, being limited to polyenic and azolic chemicals. Fluconazole is one of the most common agents used to treat vulvovaginal candidiasis [5]. 
These various difficulties have stimulated our interest in researching other effective, safe, and lowcost alternative substances, from beehive products to synthetic antifungal drugs. In Morocco, as in many other countries, beehive products are used in traditional therapy, despite the discovery of pharmaceutical synthetic processes [6]. They are considered a real treasure of bioactive compounds and an essential raw material for developing new drugs [7]. One of these products is propolis, a strongly resinous mixture of various amounts of beeswax produced by bees by mixing their saliva with resins collected from plants, particularly from flowers and leaf buds [8]. Propolis exhibits important anti-inflammatory, antimicrobial, and immunostimulatory activities $[9,10]$. In addition, it contains a variety of chemical compounds, such as phenolic acids and flavonoids. The chemical composition of propolis is strongly dependent on the area from which it is collected [11].

Despite the anticandidal activity of propolis, only a few studies have been carried out to determine the inhibitory effect of Moroccan propolis samples against candidiasis-causing pathogens $[12,13]$. Therefore, this study aimed to determine the physicochemical properties, antioxidant activity, and phenolic profile using high-performance liquid chromatography with diode array detection (HPLC-DAD), as well as to investigate the anticandidal activity of Moroccan propolis.

\section{Materials and Methods}

Ethical approval

The study was carried out according to the ethical approval obtained from Sidi Mohamed Ben Abdallah University, Fez, Morocco, under the responsibility of the Laboratory of Natural Substances, Pharmacology, Environment, Modeling, Health and Quality of Life (SNAMOPEQ), Faculty of Sciences, Dhar El Mahraz (L.20.USMBA-SNAMOPEQ).

\section{Study period and location}

The study was carried out from November 2019 to January 2020 at Laboratory of Natural Substances, Pharmacology, Environment, Modeling, Health and Quality of Life, Faculty of Sciences Dhar El Mahraz.

\section{Chemicals and reagents}

Folin-Ciocalteu reagent, sulfuric acid $\left(\mathrm{H}_{2} \mathrm{SO}_{4}\right)$, potassium-ferricyanide, 2,2-azino-bis (3-ethyl-benzothiazoline-6-sulphonic acid) (ABTS), sodium nitrite, sodium hydroxide, sodium carbonate, trichloroacetic acid, trisodium phosphate, potassium dihydrogen phosphate, and dipotassium hydrogen phosphate anhydrous, ascorbic acid, dimethyl sulfoxide (DMSO1\%), phosphate-buffered solution, bovine serum albumin (BSA), acetate buffer ( $\mathrm{pH}=3.6),(2,4,6$-tripyridyl-s-triazine) (TPTZ), and hydrochloric acid $(\mathrm{HCl})$ were procured from Merck industry (Germany). Ferricchloride hexahydrate $\left(\mathrm{FeCl}_{3}-6 \mathrm{H}_{2} \mathrm{O}\right), \mathrm{H}_{2} \mathrm{SO}_{4}$, anthrone, vanillin, aluminum trichloride $\left(\mathrm{AlCl}_{3}\right), 2,3,5$-triphenyl tetrazolium chloride (TTC) Sabouraud Dextrose agar, and broth culture medium (SDA, SDB) were obtained from Sigma-Aldrich Chemical Co. (United States of America,). Fluconazole (Diflucan $150 \mathrm{mg}$ ) was obtained from Pfizer (Morocco), vanillic acid, epicatechin, coumaric acid, ferulic acid, chlorogenic acid, ellagic acid, hesperidin, cinnamic acid, rutin, apigenin, quercetin, rosmarinic acid, naringin, and kaempferol was purchased from Abcam, United Kingdom. All chemicals were of analytical grade.

\section{Propolis samples}

After honey extraction, two propolis samples were directly collected by beekeepers from Apis mellifera hives located in the Fez-Meknes region (Table1) [11], by scratching the hive walls and frames, followed by the removal of debris of wood and bees. The samples were protected from light and immediately transferred to the laboratory in a plastic food bag at $-20^{\circ} \mathrm{C}$.

\section{Candida strains}

All clinical yeast strains used here were isolated from cases of vulvovaginal candidiasis and subsequently identified according to the standardized protocols of the University Hospital Center of Fez and to the classical mycological tests for Candida species, such as germ tube formation on fresh Human serum at $35^{\circ} \mathrm{C}$, microscopic morphology, and growth at $35^{\circ} \mathrm{C}$ for 24-48 $\mathrm{h}$.

Four Candida species were identified: C. albicans, C. glabrata, C. parapsilosis, and C. krusei. Strains were subcultured on SDA culture medium at $35^{\circ} \mathrm{C}$ for $24 \mathrm{~h}$ to ensure the purity and viability of the inocula.

\section{Extraction of balsam and moisture content}

Propolis was frozen at $-80^{\circ} \mathrm{C}$ and then pounded in a mortar until a uniform particles size was obtained. Three grams of each sample were dissolved in $30 \mathrm{~mL}$ of $70 \%$ hydro-ethanolic solution (70:30 ethanol: water), and the resulting mixture was stirred constantly for $3 \mathrm{~h}$ in a dark room. An ethanol/water mixture (70/30) is the most common solvent used for propolis extraction, as it is non-toxic and efficient, particularly for polyphenol and flavonoid extraction [14]. Subsequently, the propolis ethanolic extract was separated by a 5 min centrifugation at $2800 \mathrm{xg}$, and the supernatant was filtrated on Whatman paper, Grade 3 , as described by Popova et al. [15]. The supernatant was collected in a volumetric flask and completed up to $100 \mathrm{~mL}$ using the same $70 \%$ ethanol solvent. The final filtrates represent the balsam of propolis and are referred as propolis ethanolic extract (PEE). The yield was expressed as balsam content (soluble ethanolic fraction) and determined according to Bankova et al. [16]. Fifty milliliters of each ethanolic extract were evaporated to dryness on a rotary evaporator under reduced pressure at $40^{\circ} \mathrm{C}$. The moisture content was determined as a percentage weighting of $1 \mathrm{~g}$ of propolis that was oven-dried at $40^{\circ} \mathrm{C}$ for $16 \mathrm{~h}$. 
Table-1: Harvest date, color, and botanical origins of Moroccan propolis samples.

\begin{tabular}{llclll}
\hline Sample & Area & Geolocalisation & Vegetation Origin & $\begin{array}{l}\text { Collection } \\
\text { date }\end{array}$ & Color \\
\hline OAPEE & $\begin{array}{l}\text { Oued } \\
\text { Amlil }\end{array}$ & $34^{\circ} 12^{\prime} 0^{\prime \prime} 4^{\circ} 18^{\prime} 48^{\prime \prime} \mathrm{W}$ & Mixed native: Olea, Eucalyptus, Orange, Silybum. & $\begin{array}{l}\text { December } \\
\text { Bem }\end{array}$ & Brown \\
SFPEE & Sefrou & $33^{\circ} 49^{\prime} 48^{\prime \prime} 4^{\circ} 54^{\prime} 58^{\prime \prime} \mathrm{W}$ & $\begin{array}{l}\text { Mixed native: Olea, Pinus, Juniperus, } \\
\text { Rosmarinus, Cistus, Lavandula, and Pistacia [11] }\end{array}$ & $\begin{array}{l}\text { December } \\
2019\end{array}$ & $\begin{array}{l}\text { Dark } \\
\text { brown }\end{array}$ \\
\hline
\end{tabular}

OAPEE=Oued Amlil propolis ethanolic extrac, SFPEE=Sefrou propolis ethanolic extract

\section{Wax, resin, and total ash level determination}

The wax and resin levels in the propolis samples studied here were determined according to the method described by Papotti et al. [17], with some modifications. Briefly, $1 \mathrm{~g}$ of propolis was added to $40 \mathrm{~mL}$ of ether petroleum and heated to $40-60^{\circ} \mathrm{C}$ under magnetic stirring for $48 \mathrm{~h}$. Subsequently, $40 \mathrm{~mL}$ of $70 \%$ ethanol was added to the heated mixture under reflux until a clear solution was obtained, and the mixture was then cooled at $0^{\circ} \mathrm{C}$ for $1 \mathrm{~h}$, to promote wax separation. The results were expressed as a percentage $(\mathrm{w} / \mathrm{w})$, representing the rate of wax in the propolis sample. To determine the total ash content, an analysis was performed according to the Association of Official Agricultural Chemists [18].

\section{Preparation of dilutions}

Serial dilutions of the ethanolic extract of propolis and fluconazole standard were prepared in $1 \%$ DMSO using the following ranges from 19 to $500 \mu \mathrm{g} /$ $\mathrm{mL}$ and from 20 to $150 \mu \mathrm{g} / \mathrm{mL}$, respectively.

\section{Yield of the extraction procedure}

The yield of the extraction procedure was evaluated by comparing the dry weight of the extract with the initial weight of propolis used in the extraction using the formula:

$$
\text { Yield }=\left(\mathrm{P}_{\mathrm{e}} / \mathrm{P}_{\mathrm{m}}\right) \times 100 \%
$$

Where $P_{\text {e }}$ is the weight of propolis extract $(\mathrm{g})$ and $\mathrm{P}_{\mathrm{m}}$ is the weight of raw propolis $(\mathrm{g})$.

\section{pH determination}

To determine the $\mathrm{pH}$ of the propolis samples, a digital pH meter (model 2005, J. P. Selecta, Spain) was used. The selective ion electrode and reference electrode were placed on the support holder with $5 \mathrm{~mL}$ of PEE [19]. The $\mathrm{pH}$ values were registered after calibration of the $\mathrm{pH}$ meter readings using three buffer solutions: $\mathrm{pH} 4.0, \mathrm{pH} 6.86$, and $\mathrm{pH} 9.18$.

\section{Determination of primary metabolites Total carbohydrates}

The aliquots of PEE were dissolved in $1 \mathrm{~mL}$ of distilled water, followed by the addition of $4 \mathrm{~mL}$ of anthrone reagent prepared in $\mathrm{H}_{2} \mathrm{SO}_{4}$. The solution was incubated for $10 \mathrm{~min}$ in boiling water and the absorbance was measured at $630 \mathrm{~nm}$. A standard curve was prepared using glucose [20].

\section{Total proteins}

The total protein content of the propolis extracts was estimated using Lowry's method [21] using bovine serum albumin as a standard. The final results are expressed as mg of BSA equivalent per $100 \mathrm{~g}$ of propolis.

\section{Total lipids}

The total lipid content of the propolis extracts was determined according to the single-step method using olive oil as the standard [22]. One milliliter of PEE was mixed with $1.5 \mathrm{~mL}$ of concentrated $\mathrm{H}_{2} \mathrm{SO}_{4}$ incubated in a water bath for $10 \mathrm{~min}$. After cooling, $2.4 \mathrm{~mL}$ of vanillin reagent was added, the mixture was incubated for $40 \mathrm{~min}$ at room temperature, and the absorbance was measured at $490 \mathrm{~nm}$.

\section{Mineral composition}

The mineral composition of the propolis extracts (sodium, potassium, calcium, and magnesium) was determined using inductively coupled plasma mass spectrometry. Initially, $5 \mathrm{~mL}$ of Nitric acid $\left(\mathrm{HNO}_{3}\right)$ was added to $0.2 \mathrm{~g}$ of mineralized propolis and a power of $1000 \mathrm{~W}$ was applied for $5 \mathrm{~min}$. Subsequently, $5 \mathrm{~mL}$ of $\mathrm{HNO}_{3}$ and $1 \mathrm{~mL}$ of $30 \%$ Hydrogen peroxide were added to the solution. All samples were cooled to room temperature, made up to $100 \mathrm{~mL}$ with distilled water, and stored at $4^{\circ} \mathrm{C}$ until analysis [23].

\section{Determination of secondary metabolites Total phenolic and flavonoid content}

The total polyphenol and flavonoid contents were determined using the Folin-Ciocalteu reagent and $\mathrm{AlCl}_{3}$ method, as described by Galeotti et al. [24]. The results were expressed as $\mathrm{mg}$ of gallic acid equivalent per gram of propolis (mg GAE/g) for total polyphenol content and $\mathrm{mg}$ of quercetin equivalent per gram of propolis (mg QE/g) for total flavonoid content. To avoid the overestimation of flavonoid content in propolis, a color correction was carried out by preparing a blank under the same experimental conditions using the same amount of propolis and replacing the volume of reagents used in the test with distilled water. The absorbance of this mixture was measured and then subtracted from the initial absorbance obtained in the test.

\section{ABTS assay}

Briefly, $2.5 \mathrm{~mL}$ of ABTS reagent was mixed with $50 \mu \mathrm{L}$ of sample and incubated at room temperature for $6 \mathrm{~min}$. After incubation, the absorbance was measured at $734 \mathrm{~nm}$ using $100 \%$ methanol as a control [25]. The ABTS scavenging activity was calculated using the following formula:

$$
\% \text { ABTS scavenging }=\left[\begin{array}{ll}
\mathrm{A}_{0} & \mathrm{~A}_{1} \\
&
\end{array} \times 100\right.
$$


Where $\mathrm{A}_{0}$ and $\mathrm{A}_{1}$ are the absorbances of the control and the sample, respectively, ascorbic acid was used as a positive control and tests were carried out in duplicate.

\section{Ferric reducing antioxidant power (FRAP) assay}

The FRAP working solution was freshly prepared each time: $0.3 \mathrm{M}$ acetate buffer $(\mathrm{pH}=3.6), 0.01$ $\mathrm{M} \mathrm{TPTZ}$ in $0.04 \mathrm{M} \mathrm{HCl}$, and $0.02 \mathrm{M} \mathrm{FeCl}_{3} 6 \mathrm{H}_{2} \mathrm{O}$ were mixed at 10:1:1 (v/v/v) and kept away from light. Then, $0.075 \mathrm{~mL}$ of PEE were added to $2.25 \mathrm{~mL}$ of FRAP working solution and $0.225 \mathrm{~mL}$ of deionized water, and the mixture was vortexed and incubated at $37^{\circ} \mathrm{C}$ for $30 \mathrm{~min}$. A calibration curve was prepared using ferrous sulfate $(200,400,600,80$, and $1000 \mu \mathrm{M})$. Absorbance was recorded at $593 \mathrm{~nm}$ and the results were expressed as $\mu \mathrm{moL} \mathrm{Fe}^{2+} / \mathrm{g}$ [26]. Quercetin was used as a positive control and tests were carried out in duplicate.

\section{HPLC-DAD analysis}

The dried ethanolic extract of each propolis sample was diluted, added to methanol, and filtered through a $0.45 \mu \mathrm{M}$ membrane filter syringe before injection onto a Shimadzu prominence system equipped with a diode-array detector, a degasser, a quaternary pump (LC A20), and a Ryodine type injector. Polyphenol separation was carried out on a C18 column (Agilent Zorbax; dimensions: $4.6 \mathrm{~mm} \times 250$ $\mathrm{mm} \times 5 \mu \mathrm{M})$. The flow rate was $1 \mathrm{~mL} / \mathrm{min}$ of a mobile phase composed of a ternary gradient of acetonitrile, methanol, and acidified water; the temperature of the column was $30^{\circ} \mathrm{C}$; and the injection volume was 20 $\mu \mathrm{L}$. Under the same conditions, standard solutions, syringic acid, and tyrosol were injected, to determine the response factor. Pure compounds were used as standards, including:

- Phenolic acids: Vanillic acid, coumaric acid, ferulic acid, cinnamic acid, gallic acid, chlorogenic acid, rosmarinic acid, and ellagic acid.

- Flavonoids: Hesperidin, epicatechin, rutin, apigenin, quercetin, naringin, and kaempferol.

Phenolic compounds were identified by comparing their ultraviolet-visible spectra and retention times with those of the corresponding standards, and chromatographic data were acquired using the LabSolutions software equipped with a spectral identification module for the separated compounds; the results are expressed as $\mathrm{mg} / \mathrm{g}$ of propolis [27].

\section{In vitro antifungal susceptibility test}

The antifungal activity was determined using microtitration plates and the TTC dye method for all Candida strains [28]. Briefly, inocula were prepared in $0.9 \%$ sterile saline, and their turbidity was adjusted to $0.5 \mathrm{McF}$ arland. Initially, $170 \mu \mathrm{L}$ of SDB medium was distributed in the plate wells, and $10 \mu \mathrm{L}$ of each propolis ethanolic extract sample was transferred to the wells at concentrations ranging from 1.95 to 1000 $\mu \mathrm{g} / \mathrm{mL}$. Finally, $20 \mu \mathrm{L}$ of adjusted inocula from each strain was added to each well. Positive and negative controls were also included (with and without Candida suspension, respectively). A serial dilution of fluconazole was used as a standard drug. The MIC values were determined after $24 \mathrm{~h}$ of incubation at $35^{\circ} \mathrm{C}$; the lowest concentration that could visibly inhibit fungal growth was considered as the MIC. Subsequently, $10 \mu \mathrm{L}$ of the TTC dye was used to confirm the presence of viable microorganisms, as it reflects the activity of the dehydrogenase enzymes involved in the process of cell respiration [29]. This technique is widely used to determine the MIC, because in the presence of bacteria or fungi, TTC is reduced to red-colored formazan, which is directly proportional to the quantity of viable cells [30]. This test was performed in duplicate.

After MIC determination, the content of the well corresponding to the MIC and the content of the two preceding concentrations were subcultured in SDA Petri dishes and incubated at $35^{\circ} \mathrm{C}$ for $48 \mathrm{~h}$. The MFC was defined as the lowest concentration that was able to inhibit Candida species growth. The MFC/MIC ratio was calculated to determine whether the $\mathrm{PEE}$ had a fungistatic $(\mathrm{MFC} / \mathrm{MIC} \geq 4)$ or fungicidal (MFC/MIC<4) activity [31].

\section{Statistical analysis}

The tests were performed in duplicate, and the results were expressed as the mean \pm standard deviation. Statistical comparisons were carried out with a one-way analysis of variance using the Minitab 18 software (Minitab, Ltd., Brandon Court, Unit E1-E2 Progress Way, Coventry, CV3 2TE, UK).

\section{Results and Discussion}

The physicochemical characterization of the Moroccan propolis samples studied here is presented in Table-2. The results showed that the extraction yields were significantly higher in the Sefrou propolis ethanolic extract (SFPEE) (18.3\%) versus the Oued amlil propolis ethanolic extract (OAPEE) (15.8\%) sample, and that both samples had an acidic $\mathrm{pH}$. These results were similar to those obtained for Indonesian propolis, which exhibited a yield and $\mathrm{pH}$ of $18.3 \%$ and 5.4 , respectively [32].

In general, propolis consists of about $50 \%$ resin and $30 \%$ wax [33]. Our results indicated that the contents of resin and wax of the OAPEE sample were significantly higher than those of the SFPEE sample. In turn, balsam and moisture levels are used to determine propolis quality: A high humidity content in propolis indicates bad storage and manipulation conditions [34]. The studied propolis samples showed that the moisture and balsam levels in the OAPEE sample were significantly higher than those of the SFPEE sample $(2.00 \% \pm 0.09 \%$ vs. $1.09 \% \pm 0.05 \%$; and $0.71 \% \pm 0.05 \%$ vs. $0.68 \% \pm 0.03 \%$ ), respectively. These results are within the ranges reported for Slovenian propolis samples [35].

The determination of total ash content is particularly important for propolis samples, as this analysis can 
identify the possible adulteration of the material through the presence of impurities, or even residues, from previously extracted propolis [36]. In the present study, the obtained ash values $(1.79 \% \pm 0.19 \%$ in the OAPEE and $1.84 \% \pm 0.11 \%$ in the SFPEE sample) were similar to those obtained in propolis samples from Brazil [37].

The total carbohydrate content was similar in both samples $(1.01 \pm 0.05 \mathrm{gGlcEq} / \mathrm{g}$ in the OAPEE vs. $0.98 \pm 0.03 \mathrm{gGlcEq} / \mathrm{g}$ in the SFPEE sample). In contrast, the content of total proteins was significantly higher in the OAPEE versus the SFPEE sample, with the opposite relationship being observed for total lipids (Table-3). The values obtained were similar to those detected in Iranian propolis [38]. In addition, minerals are among the essential micronutrients that exist in propolis and may contribute to the pharmacological properties of this beehive product [39]. A high content of minerals (sodium, potassium, calcium, and magnesium) was observed in the SFPEE sample. The values obtained in this study were slightly higher than those found for Malaysian propolis [40].

The total polyphenol contents of the Moroccan propolis samples depended significantly on the sampling area and the surrounding flora of the hives (Table-1). The TPC level in the SFPEE sample was significantly higher than that of the OAPEE sample (194.68 $\pm 2.07 \mathrm{mgGAE} / \mathrm{g}$ vs. $117.38 \pm 1.86 \mathrm{mgGAE} / \mathrm{g})$ (Table-4). These values agree with those obtained for Algerian and Lithuanian propolis, in which the TPC ranged from 19.51 to $219.66 \mathrm{mgGAE} / \mathrm{g}$ and from 95.02 to $196.81 \mathrm{mgGAE} / \mathrm{g}[41,42]$, respectively. However, the TPC levels detected in this study were considerably higher than those found in propolis from Tunisia, which ranged from 17.34 to $33.4 \mathrm{mgGAE} / \mathrm{g}$ [43].

The total flavonoid content of the studied propolis samples was $17.45 \pm 1.06 \mathrm{mgQE} / \mathrm{g}$ for the OAPEE and $24.79 \pm 0.78 \mathrm{mgQE} / \mathrm{g}$ for the SFPEE (Table-4). These values are similar to those obtained for a propolis extract from South Korea, in which TFC was present in the range of 21-50 $\mathrm{mgQE} / \mathrm{g}$ [44], and lower than those obtained for propolis from Mexico (13-379 mgQE/g [45] and Turkey (522.71 mg $\mathrm{QE} / \mathrm{g})$ [46]. Whereas the obtained results were higher than those described for the propolis from Algeria (0.57-3.53 mgQE/g) [47]. These variations in the TPC and TFC values may be attributed to the botanical and geographic origins of the samples and bee species, the harvest year, and seasonal variations [48].

Two different methods were used to assess the antioxidant activity of propolis (ABTS and FRAP). Both samples possessed potent antioxidant activity, although with significant differences. The FRAP test showed that the half-maximal effective concentration of the OAPEE was $100.57 \pm 2.13 \mu \mathrm{moL} \mathrm{Fe}{ }^{2+} / \mathrm{g}$, whereas that of the SFPEE was $118.78 \pm 4.27 \mu \mathrm{moL}$ $\mathrm{Fe}^{2+} / \mathrm{g}$. Conversely, the Half-maximal inhibitory concentration $\left(\mathrm{IC}_{50}\right)$ values of the ABTS test revealed that the SFPEE $\left(\mathrm{IC}_{50}=72.50 \pm 0.42 \mu \mathrm{g} / \mathrm{mL}\right)$ was more potent than the OAPEE $\left(\mathrm{IC}_{50}=115.5 \pm 0.67\right)$ (Table-4). The results of the ABTS test were in the range of those obtained for Palestinian propolis [49] and higher than those found in Greek propolis [50]. For the FRAP assay, the obtained values were higher than those obtained for propolis from Venezuela [51].

Table-2: Quantitative estimation of propolis physicochemical parameters.

\begin{tabular}{lccccccc}
\hline Propolis Sample & Yield (\%) & pH & Resin (\%) & Wax (\%) & Balsams (\%) & Moisture (\%) & Ash (\%) \\
\hline OAPEE & $15.8 \pm 0.40$ & $5.9 \pm 0.30 *$ & $59.8 \pm 2.20 *$ & $28.9 \pm 0.20 *$ & $0.71 \pm 0.05 *$ & $2.00 \pm 0.09 *$ & $1.79 \pm 0.19$ \\
SFPEE & $18.3 \pm 1.80 *$ & $4.8 \pm 0.30$ & $48.3 \pm 1.80$ & $21.8 \pm 0.50$ & $0.68 \pm 0.03$ & $1.09 \pm 0.05$ & $1.84 \pm 0.11 *$
\end{tabular}

$\mathrm{SD}=$ Standard deviation for duplicate determination; the results are presented as mean $\pm \mathrm{SD}(* \mathrm{p}<0.05)$.

OAPEE=Oued Amlil propolis ethanolic extract; SFPEE=Sefrou propolis ethanolic extract, SD=Standard deviation

Table-3: Total carbohydrates, proteins, lipids, and minerals content in propolis samples.

\begin{tabular}{lccccccc}
\hline $\begin{array}{l}\text { Propolis } \\
\text { Sample }\end{array}$ & $\begin{array}{c}\text { T. carbs } \\
(\mathbf{g G l c E q} / \mathbf{g})\end{array}$ & $\begin{array}{c}\text { T. prot } \\
(\mathbf{g} / \mathbf{1 0 0 g})\end{array}$ & $\begin{array}{c}\text { T. lip } \\
(\mathbf{m g} / \mathbf{g})\end{array}$ & $\begin{array}{c}\text { Magnesium } \\
(\mu \mathbf{g} / \mathbf{g})\end{array}$ & $\begin{array}{c}\text { Sodium } \\
(\boldsymbol{\mu g} / \mathbf{g})\end{array}$ & $\begin{array}{c}\text { Potassium } \\
(\mu \mathbf{g} / \mathbf{g})\end{array}$ & $\begin{array}{c}\text { Calcium } \\
(\mu \mathbf{g} / \mathbf{g})\end{array}$ \\
\hline OAPEE & $1.01 \pm 0.05$ & $0.99 \pm 0.05$ & $120 \pm 0.08^{*}$ & $6.9 \pm 0.02$ & $18.6 \pm 0.03$ & $25.7 \pm 0.02$ & $6.4 \pm 0.02$ \\
SFPEE & $0.98 \pm 0.03$ & $2.5 \pm 0.09 *$ & $108 \pm 0.05$ & $13.6 \pm 0.02 * *$ & $33 \pm 0.02 * *$ & $53.6 \pm 0.02 * *$ & $10.9 \pm 0.02 *$ \\
\hline
\end{tabular}

OAPEE=Oued Amlil propolis ethanolic extract, SFPEE=Sefrou propolis ethanolic extract. T. carbs: Total carbohydrates, T. Prot: Total proteins, T. Lip: Total lipids. ${ }^{*} \mathrm{SD}=$ Standard deviation for duplicate determination; the results are presented as mean \pm SD $(* p<0.05)$, $(* * p<0.01)$

Table-4: Antioxidant activity of Moroccan propolis studied.

\begin{tabular}{|c|c|c|c|c|}
\hline Sample & TPC (mg GAE/g) & TFC (mg QE/g) & FRAP-EC $_{50}\left(\mu \mathrm{moL} \mathbf{F e}^{2}+/ \mathbf{g}\right)$ & ABTS-IC $_{50}(\mu \mathrm{g} / \mathrm{mL})$ \\
\hline OAPEE & $117.38 \pm 1.86$ & $17.45 \pm 1.06$ & $100.57 \pm 2.13$ & $115.5 \pm 0.67 * *$ \\
\hline SFPEE & $194.68 \pm 2.07 *$ & $24.79 \pm 0.78 * *$ & $118.78 \pm 4.27^{*}$ & $72.50 \pm 0.42$ \\
\hline $\mathrm{BHT}$ & - & - & - & - \\
\hline $\mathrm{Q}$ & - & - & $93.09 \pm 1.68$ & - \\
\hline AA & - & - & - & $28.6 \pm 1.09$ \\
\hline
\end{tabular}

OAPEE=Oued Amlil propolis ethanolic extract, SFPEE=Sefrou propolis ethanolic extract. TPC=Total polyphenols content, TFC=Total flavonoids content, $\mathrm{Q}=$ quercetin, $\mathrm{AA}=$ ascorbic acid. $* \mathrm{SD}$-standard deviation for duplicate determination; the results are presented as mean $\pm S D(* p<0.05),(* * p<0.01) . E_{50}=$ Half maximal effective concentration 
The quantification of phenolic compounds in the propolis samples was performed using HPLC-DAD. The results revealed the presence of 13 compounds, with the highest concentration registered for epicatechin $(310 \pm 28.30 \mathrm{mg} / \mathrm{g})$ in the OAPEE and for apigenin $(410 \pm 21.20 \mathrm{mg} / \mathrm{g})$ in the SFPEE. However, gallic and chlorogenic acids were not detected in either sample (Table-5 and Figure-1). The results obtained here indicated a similarity in phenolic compounds among the propolis samples, regardless of their botanical and geographical origin. Similarly, in a study conducted by Osés

Table-5: Phenolic compounds of Moroccan propolis studied.

\begin{tabular}{lcc}
\hline $\begin{array}{l}\text { Phenolic Acids/ } \\
\text { Flavonoids }\end{array}$ & \multicolumn{2}{c}{ Propolis samples } \\
\cline { 2 - 3 } & OAPEE $\mathbf{( m g / g )}$ & $\begin{array}{c}\text { SFPE SFPEE } \\
\mathbf{( m g / g )}\end{array}$ \\
\hline Vanillic acid & $3 \pm 0.70$ & $13 \pm 2.83^{* * *}$ \\
Epicatechin & $310 \pm 28.30$ & $269 \pm 26.9$ \\
Gallic acid & $\mathrm{ND}$ & $\mathrm{ND}$ \\
Coumaric acid & $6.41 \pm 0.58$ & $16 \pm 4.24 * *$ \\
Ferulic acid & $28.80 \pm 3.96 * *$ & $7.60 \pm 0.84$ \\
Ellagic acid & $98 \pm 4.24 *$ & $56 \pm 7.07$ \\
Chlorogenic acid & $\mathrm{ND}$ & $\mathrm{ND}$ \\
Hesperidin & $101 \pm 4.24$ & $145 \pm 9.90^{*}$ \\
Apigenin & $245 \pm 21.20$ & $410 \pm 21.20^{* * *}$ \\
Cinnamic acid & $18 \pm 1.41$ & $38 \pm 2.12^{* *}$ \\
Rosmarinic acid & $47 \pm 2.83$ & $68 \pm 4.24 * *$ \\
Rutin & $35.9 \pm 2.69$ & $60.0 \pm 2.83^{* *}$ \\
Naringin & $68 \pm 4.24$ & $99 \pm 2.83^{* *}$ \\
Quercetin & $87 \pm 7.07 * *$ & $32 \pm 2.83$ \\
Kaempferol & $107 \pm 7.07$ & $150 \pm 2.83^{*}$ \\
\hline OAPEE Oued
\end{tabular}

OAPEE=Oued Amlil propolis ethanolic extract, SFPEE $=$ Sefrou propolis ethanolic extract. $S D=$ Standard deviation for duplicate determination; the results are presented as mean \pm SD. $(* p<0.05)$, $(* * p<0.01)$, $(* * * p<0.001)$ et al. [52], p-coumaric and ferulic acids were found in 13 propolis samples from different geographical areas.

The phenolic composition of propolis can be used to standardize this beehive product. For instance, Özkök et al. [53] showed that caffeic acid, caffeic acid phenethyl ester, galangin, and pinocembrin could be markers of Turkish propolis. In turn, Polish propolis was characterized by $p$-coumaric acid, 2-acetyl-1,3di-p-coumaryl glycerol, and $p$-coumaric acid benzyl ester, together with galangin and chrysin as the main polyphenols [54]. In Italian propolis, pinocembrin was one of the most important flavonoids, and isoferulic, ferulic, and caffeic acids were the major phenolic acids [55]. The antifungal activity of propolis against yeasts is attributed to its rich composition in phenolic acids, flavonoids, and esters [56]. In this study, the ethanolic extracts of the Moroccan propolis samples proved their efficacy in vitro against all clinical Candida isolates. The obtained MIC and MFC values were close to the reference drug fluconazole (Table-6). These results are superior to those reported for Romanian propolis against Candida strains, which ranged between $230 \mu \mathrm{g} / \mathrm{mL}$ and $15000 \mu \mathrm{g} / \mathrm{mL}$ [57]. However, it was found that Turkish propolis was more potent in the inhibition of C. albicans and C. glabrata, as its MIC values ranged from 0.006 to 0.05 and from 0.025 to $0.1 \mu \mathrm{g} / \mathrm{mL}$, respectively [58]. In contrast, in Spanish propolis, the antifungal activity against C. glabrata was supported by MIC values ranging between 60 and $240 \mu \mathrm{g} / \mathrm{mL}$ [59].

The anticandidal activity of propolis may be attributed to its polyphenol content. For instance, in a study conducted by Quiroga et al. [60], it was found that pinocembrin and galangin isolated from

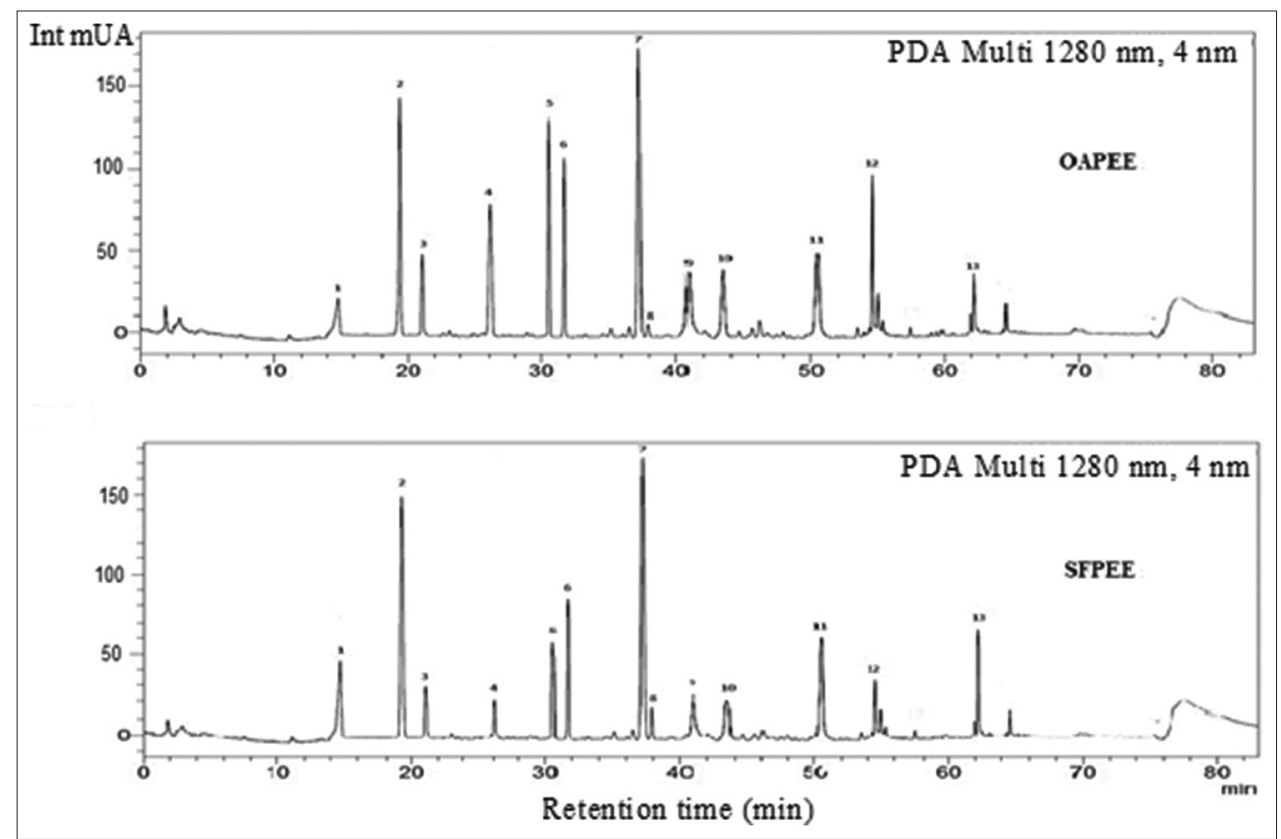

Figure-1: Chromatograms of OAPEE and SFPEE with identified phenolics, (1) vanillic acid, (2) epicatechin, (3) coumaric acid, (4) ferulic acid, (5) ellagic acid, (6) hesperidin, (7) apigenin, (8) cinnamic acid, (9) rosmarinic acid, (10) rutin, (11) naringin, (12) quercetin and (13) kaempferol. OAPEE=Oued Amlil propolis ethanolic extract, SFPEE=Sefrou propolis ethanolic extract. 
Table-6: Anticandidal activity of Moroccan propolis against clinical Candida species.

\begin{tabular}{lcccc}
\hline Samples & \multicolumn{3}{c}{ Candida species } \\
\cline { 2 - 5 } & Candida albicans & Candida glabrata & Candida krusei & Candida parapsilosis \\
\hline OAPEE & 62.5 & 62.5 & 62.5 & 31.2 \\
MIC $(\mu \mathrm{g} / \mathrm{mL})$ & 125 & 125 & 125 & 62.5 \\
MFC $(\mu \mathrm{g} / \mathrm{mL})$ & 2 & 2 & 2 & 2 \\
R & 62.5 & 62.5 & 62.5 & 31.2 \\
SFPEE & 125 & 125 & 125 & 62.5 \\
MIC $(\mu \mathrm{g} / \mathrm{mL})$ & 2 & 2 & 2 & 2 \\
MFC $(\mu \mathrm{g} / \mathrm{mL})$ & 46 & 46 & 93 & 37.5 \\
R & 93 & 93 & 187 & 75 \\
FLZ & 2 & 2 & 2 & 2 \\
MIC $(\mu \mathrm{g} / \mathrm{mL})$ & MFC $(\mu \mathrm{g} / \mathrm{mL})$ & & & \\
R & & & & \\
\hline
\end{tabular}

OAPEE =Oued Amlil propolis ethanolic extract, SFPEE=Sefrou propolis ethanolic extract, MIC, MFC=Concentrations by $\mu \mathrm{g} / \mathrm{mL}$, FLZ: fluconazole standard drug. R=MIC/MFC, MIC=Minimum inhibitory concentration, MFC=Minimum fungicidal concentration

Argentinian propolis were partially responsible for its fungitoxic activity. In addition, vanillin, 4-coumaric acid, and methyl ferulate are among the molecules reported to be good inhibitors of biofilm formation in microorganisms, including C. albicans [61].

It was proven that the antifungal activity of propolis can be attributed to the inhibition of the formation of the hyphal forms of $\mathrm{C}$. albicans, which represent an important factor of virulence of these pathogenic yeasts. In addition, it was reported that a mixture of antifungal drugs with propolis can lead to synergistic effects and improved results [62].

\section{Conclusion}

The Moroccan propolis showed good physicochemical characteristics and rich chemical composition, including minerals, flavonoids, and phenolic acids. In addition, they were endowed with an important antifungal activity, which renders them a potential therapeutic agent that may be useful in the prevention and treatment of candidiasis infections. Further studies are needed to identify the bioactive molecule responsible for the antimycotic activity of propolis and to determine its mechanism of action.

\section{Data Availability}

The supplementary data can be available from the corresponding author upon a reasonable request.

\section{Authors' Contributions}

AA: Propolis harvesting, extraction, antioxidant and antifungal activity, and drafting of the manuscript. ST: Propolis sampling and clinical candida strain isolation and the interpretations of the results. MF: Performed data treatment and physicochemical analysis. BL: Conceived and designed the study. All authors read and approved the final manuscript.

\section{Acknowledgments}

The authors would like to thank Laboratory (SNAMOPEQ), Faculty of Sciences, Dhar El Mehraz,
Morocco, for providing the necessary facilities for the study. The study was funded by the University Sidi Mohamed Ben Abdallah (Grant no. USMBA, SNAMOPEQ 20), Fez, Morocco.

\section{Competing Interests}

The authors declare that they have no competing interests.

\section{Publisher's Note}

Veterinary World remains neutral with regard to jurisdictional claims in published institutional affiliation.

\section{References}

1. Brown, G.D., Denning, D.W. and Levitz, S.M. (2012) Tackling Human Fungal Infections. Science, 336(6082): 647-647.

2. Falagas, M.E., Roussos, N. and Vardakas, K.Z. (2010) Relative frequency of albicans and the various non-albicans Candida spp. among candidemia isolates from inpatients in various parts of the world: A systematic review. Int. J. Infect. Dis., 14(11): e954-e966.

3. Pfaller, M.A., Diekema, D.J., Gibbs, D.L., Newell, V.A., Ellis, D., Tullio, V., Rodloff, A., Fu, W. and Ling, T.A. (2010) Results from the Artemis disk global antifungal surveillance study, 1997 to 2007: A 10.5-year analysis of susceptibilities of Candida species to fluconazole and voriconazole as determined by CLSI standardized disk diffusion. J. Clin. Microbiol., 48(4): 1366-1377.

4. Perfect, J.R. (2017) The antifungal pipeline: A reality check. Nat. Rev. Drug Discov., 16(9): 603-616.

5. Al-Hatamleh, M.A.I., Boer, J.C., Wilson, K.L., Plebanski, M., Mohamud, R. and Mustafa, M.Z. (2020) Antioxidant-based medicinal properties of stingless bee products: Recent progress and future directions. Biomolecules, 10(6): 923.

6. Aminimoghadamfarouj, N. and Nematollahi, A. (2017) Propolis diterpenes as a remarkable bio-source for drug discovery development: A review. Int. J. Mol. Sci., 18(6): 1290.

7. Drescher, N., Klein, A.M., Schmitt, T. and Leonhardt, S.D. (2019) A clue on bee glue: New insight into the sources and factors driving resin intake in honeybees (Apis mellifera). PLoS One, 14(2): e0210594.

8. El-Guendouz, S., Aazza, S., Lyoussi, B., Bankova, V., Popova, M., Neto, L., Faleiro, M.L. and da Graça Miguel, M. (2018) Moroccan propolis: A natural antioxidant, 
antibacterial, and antibiofilm against Staphylococcus aureus with no induction of resistance after continuous exposure. Evid. Based Complement. Alternat. Med., 2018: 9759240.

9. Chan, G.C.F., Cheung, K.W. and Sze, D.M.Y. (2013) The immunomodulatory and anticancer properties of propolis. Clin. Rev. Allergy Immunol., 44(3): 262-273.

10. Huang, S., Zhang, C.P., Wang, K., Li, G.Q. and Hu, F.L. (2014) Recent advances in the chemical composition of propolis. Molecules, 19(12): 19610-19632.

11. Touzani, S., Embaslat, W., Imtara, H., Kmail, A., Kadan, S., Zaid, H., Elarabi, I., Badiaa, L., Saad, B. and Kabir, Y. (2019) In vitro evaluation of the potential use of propolis as a multitarget therapeutic product: Physicochemical properties, chemical composition, and immunomodulatory, antibacterial, and anticancer properties. Biomed Res. Int., 2019: 4836378.

12. El-Guendouz, S., Lyoussi, B. and Miguel, M.G. (2019) Insight on propolis from Mediterranean countries: chemical composition, biological activities and application fields. Chem. Biodivers., 16(7): e1900094.

13. Touzani, S., Al-Waili, N., El Menyiy, N., Filipic, B., Pereyra, A., EL Arabi, I., AL-Waili, W. and Lyoussi, B. (2018) Chemical analysis and antioxidant content of various propolis samples collected from different regions and their impact on antimicrobial activities. Asian Pac. J. Trop. Med., 11(7): 436.

14. Bach, L.G., van Muoi, N., Pham, T.N., Nguyen, V.T., Toan, T.Q., Cang, M.H., Giang Bach, L. and van Muoi, N. (2020) Effects of various processing parameters on polyphenols, flavonoids, and antioxidant activities of Codonopsis javanica root extract. Nat. Prod. Commun., 15(9): 1-12.

15. Popova, M.P., Bankova, V.S., Bogdanov, S., Tsvetkova, I., Naydenski, C., Marcazzan, G.L. and Sabatini, A.G. (2007) Chemical characteristics of poplar type propolis of different geographic origin. Apidologie, 38(3): 306-311.

16. Bankova, V., Bertelli, D., Borba, R., Conti, B.J., da Silva Cunha, I.B., Danert, C., Eberlin, M.N., I Falcão, S., Isla, M.I., Moreno, M.I.N., Papotti, G., Popova, M., Santiago, K.B., Salas, A., Sawaya, A.C.H., Schwab, N.V., Sforcin, J.M., Simone-Finstrom, M, Spivak, M., Trusheva, B., VilasBoas, M., Wilson, M. and Zampini, C. (2016) Standard methods for Apis mellifera propolis research. J. Apic. Res., 58(2): 1-49.

17. Papotti, G., Bertelli, D., Bortolotti, L. and Plessi, M. (2012) Chemical and functional characterization of Italian propolis obtained by different harvesting methods. J. Agric. Food Chem., 60(11): 2852-2862.

18. AOAC. (2016) Official Methods of Analysis of AOAC International. $20^{\text {th }}$ ed. AOAC, Washington, DC, United States. Available from: https://www.techstreet.com/standards/official-methods-of-analysis-of-aoac-international-20th-edition-2016?product_id=1937367 Retrieved on 10-12-2021.

19. Dias, L.G., Pereira, A.P. and Estevinho, L.M. (2012) Comparative study of different Portuguese samples of propolis: Pollinic, sensorial, physicochemical, microbiological characterization and antibacterial activity. Food Chem. Toxicol., 50(12): 4246-4253.

20. Kaewmuangmoon, J., Nonthapa, P., Rattanawannee, A., Winayanuwattikun, P. and Chanchao, C. (2012) Preliminary screening for various bioactivities in honey and propolis extracts from Thai bees. Eur. J. Med. Plants., 2(2): 74-92.

21. Mæhre, H.K., Dalheim, L., Edvinsen, G.K., Elvevoll, E.O. and Jensen, I.J. (2018) Protein determination-method matters. Foods, 7(1): 5.

22. Axelsson, M. and Gentili, F. (2014) A single-step method for rapid extraction of total lipids from green microalgae. PLoS One, 9(2): e89643.

23. González-Martín, M.I., Escuredo, O., Revilla, I., VivarQuintana, A.M., Coello, M.C., Riocerezo, C.P. and Moncada, G.W. (2015) Determination of the mineral composition and toxic element contents of propolis by near infrared spectroscopy. Sensors, 15(11): 27854-27868.

24. Galeotti, F., Maccari, F., Fachini, A. and Volpi, N. (2018) Chemical composition and antioxidant activity of propolis prepared in different forms and in different solvents useful for finished products. Foods, 7(3): 41.

25. Martinello, M. and Mutinelli, F. (2021) Antioxidant activity in bee products: A review. Antioxidants, 10(1): 71.

26. Daraghmeh, J. and Imtara, H. (2020) In vitro evaluation of Palestinian propolis as a natural product with antioxidant properties and antimicrobial activity against multidrug-resistant clinical isolates. J. Food Qual., 2020: 8861395.

27. Sun, S., He, J., Liu, M., Yin, G. and Zhang, X. (2019) A great concern regarding the authenticity identification and quality control of Chinese propolis and Brazilian green propolis. J. Food Nutr. Res., 7(10): 725-735.

28. Rex, J.H. (2002) Reference Method for Broth Dilution Antifungal Susceptibility Testing of Yeasts, Approved Standard. $3^{\text {rd }}$ ed. Clinical and Laboratory Standards Institute, United States.

29. da Silva, I.C.G., de Pontes Santos, H.B., Cavalcanti, Y.W., Nonaka, C.F.W., de Sousa, S.A. and de Castro, R.D. (2017) Antifungal activity of eugenol and Its association with nystatin on Candida albicans. Pesqui. Bras. Odontopediatria Clin. Integr., 17(1): 1-8.

30. Veiga, A., Toledo, M. da G.T., Rossa, L.S., Mengarda, M., Stofella, N.C.F., Oliveira, L.J., Gonçalves, A.G. and Murakami, F.S. (2019) Colorimetric microdilution assay: Validation of a standard method for determination of MIC, IC $50 \%$, and IC $90 \%$ of antimicrobial compounds. $J$. Microbiol. Methods, 162: 50-61.

31. de Castro, R.D., de Souza, T.M.P., Bezerra, L.M.D., Ferreira, G.L.S., de Brito Costa, E.M.M. and Cavalcanti,A.L. (2015) Antifungal activity and mode of action of thymol and its synergism with nystatin against Candida species involved with Infections in the oral cavity: An in vitro study. BMC Complement Altern. Med., 15(1): 1-7.

32. Pujirahayu, N., Ritonga, H. and Uslinawaty, Z. (2014) Properties and flavonoids content in propolis of some extraction method of raw propolis. Int. J. Pharm. Pharm. Sci., 6(6): 338-340.

33. Saccardi, L., Schiebl, J., Weber, K., Schwarz, O., Gorb, S. and Kovalev, A. (2021) Adhesive behavior of propolis on different substrates. Front. Mech. Eng., 7(32): 660517.

34. Serra-Bonvehí, J. and Orantes-Bermej, F.J. (2013) Element content of propolis collected from different areas of South Spain. Environ. Monit. Assess., 185(7): 6035-6047.

35. Šturm, L. and Ulrih, N.P. (2019) Advances in the propolis chemical composition between 2013 and 2018: A review. eFood, 1(1): 24-37.

36. Correa-González, Y.X., Rojas-Cardozo, M.A., MoraHuertas, C.E., Correa-González, Y.X., Rojas-Cardozo, M.A. and Mora-Huertas, C.E. (2019) Potentialities of the colombian propolis in pharmaceutics and cosmetics: A standpoint from the quality control. Rev. Colomb. Cienc. Quim. Farm., 48(3): 762-788.

37. Devequi-Nunes, D., Machado, B.A.S., de Abreu Barreto, G., Silva, J.R., da Silva, D.F., da Rocha, J.L.C., Brandão, H.N., Borges, V.M. and Umsza-Guez, M.A. (2018) Chemical characterization and biological activity of six different extracts of propolis through conventional methods and supercritical extraction. PLoS One, 13(12): e0207676.

38. Fallah, M., Naja, F. and Kavoosi, G. (2021) Bee Propolis, Bee Bread, and Royal Jelly: Proximate Analysis, Fatty Acid Composition, Nutritional Quality, and Anti-Amylase Activity.

39. Pasupuleti, V.R., Sammugam, L., Ramesh, N. and Gan, S.H. (2017) Honey, propolis, and royal jelly: A comprehensive review of their biological actions and health benefits. Oxid. Med. Cell Longev., 2017: 1259510.

40. Abdullah, N.A., Zullkiflee, N., Zaini, S.N.Z., Taha, H., Hashim, F. and Usman, A. (2020) Phytochemicals, mineral contents, antioxidants, and antimicrobial activities of 
propolis produced by brunei stingless bees geniotrigona thoracica, heterotrigona itama, and tetrigona binghami. Saudi J. Biol. Sci., 27(11): 2902-2911.

41. Soltani, E.K., Zaim, K., Mokhnache, K., Haichour, N., Mezaache-Aichour, S., Charef, N. and Zerroug, M.M. (2021) Polyphenol contents, antioxidant and antibacterial activities of aqueous Algerian propolis extracts. Phytothérapie, 27(11): 2902-2911.

42. Stanciauskaite, M., Marksa, M., Liaudanskas, M., Ivanauskas, L., Ivaskiene, M. and Ramanauskiene, K. (2021) Extracts of poplar buds (Populus balsamifera L., Populus nigra L.) and Lithuanian Propolis: Comparison of their composition and biological activities. Plants, 10(5): 828 .

43. Gargouri, W., Osés, S.M., Fernández-Muiño, M.A., Sancho, M.T. and Kechaou, N. (2019) Evaluation of bioactive compounds and biological activities of Tunisian propolis. $L W T, 111: 328-336$.

44. Wang, X., Sankarapandian, K., Cheng, Y., Woo, S.O., Kwon, H.W., Perumalsamy, H. and Ahn, Y.J. (2016) Relationship between total phenolic contents and biological properties of propolis from 20 different regions in South Korea. BMC Complement Altern. Med., 16(1): 1-12.

45. Hernández Zarate, M.S., Abraham Juárez, M.R., Cerón García, A., Ozuna López, C., Gutiérrez Chávez, A.J., Segoviano Garfias, J.J.N. and Avila Ramos, F. (2018) Flavonoids, phenolic content, and antioxidant activity of propolis from various areas of Guanajuato, Mexico. Food Sci. Technol., 38(2): 210-215.

46. Ozdal, T., Sari-Kaplan, G., Mutlu-Altundag, E., Boyacioglu, D. and Capanoglu, E. (2018) Evaluation of Turkish propolis for its chemical composition, antioxidant capacity, anti-proliferative effect on several human breast cancer cell lines and proliferative effect on fibroblasts and mouse mesenchymal stem cell line. J. Apic. Res., 57(5): 627-638.

47. Bouaroura, A., Segueni, N., Diaz, J.G., Bensouici, C., Akkal, S. and Rhouati, S. (2020) Preliminary analysis of the chemical composition, antioxidant and anticholinesterase activities of Algerian propolis. Nat. Prod. Res., 34(22): 3257-3261.

48. Dezmirean, D.S., Paşca, C., Moise, A.R. and Bobiş, O. (2020) Plant sources responsible for the chemical composition and main bioactive properties of poplar-type propolis. Plants, 10(1): 22.

49. Touzani, S., Imtara, H., Katekhaye, S., Mechchate, H., Ouassou, H., Alqahtani, A.S., Noman, O.M., Nasr, F.A., Fearnley, H., Fearnley, J., Paradkar, A., ElArabi, I. and Lyoussi, B. (2021) Determination of phenolic compounds in various propolis samples collected from an African and an Asian region and their impact on antioxidant and antibacterial activities. Molecules, 26(15): 4589.

50. Stavropoulou, M.I., Stathopoulou, K., Cheilari, A., Benaki, D., Gardikis, K., Chinou, I. and Aligiannis, N. (2021) NMR metabolic profiling of Greek propolis samples: Comparative evaluation of their phytochemical compositions and investigation of their anti-aging and antioxidant properties. J. Pharm. Biomed. Anal., 194: 113814.

51. Mohtar, L.G., Messina, G.A., Bertolino, F.A., Pereira, S.V., Raba, J. and Nazareno, M.A. (2020) Comparative study of different methodologies for the determination of the antioxidant activity of Venezuelan propolis. Microchem. J., 158: 105244.

52. Osés, S.M., Marcos, P., Azofra, P., de Pabl, A., FernándezMuíño, M.Á. and Sancho, M.T. (2020) Phenolic profile, antioxidant capacities and enzymatic inhibitory activities of propolis from different geographical areas: Needs for analytical harmonization. Antioxidants, 9(1): 75.

53. Özkök, A., Keskin, M., Tanuğur Samanc1, A.E., Yorulmaz Önder, E. and Takma, Ç. (2021) Determination of antioxidant activity and phenolic compounds for basic standardization of Turkish propolis. Appl. Biol. Chem., 64(1): 1-10.

54. Okinczyc, P., Szumny, A., Szperlik, J., Kulma, A., Franiczek, R., Zbikowska, B., Krzyzanowska, B. and Sroka, Z. (2018) Profile of polyphenolic and essential oil composition of Polish propolis, black poplar and aspens buds. Molecules, 23(6): 1262.

55. Gardini, S., Bertelli, D., Marchetti, L., Graziosi, R., Pinetti, D., Plessi, M. and Marcazzan, G.L. (2018) Chemical composition of Italian propolis of different ecoregional origin. J. Apic. Res., 57(5): 639-647.

56. Ramón-Sierra, J., Peraza-López, E., Rodríguez-Borges, R., Yam-Puc, A., Madera-Santana, T. and Ortiz-Vázquez, E. (2019) Partial characterization of ethanolic extract of melipona beecheii propolis and in vitro evaluation of its antifungal activity. Rev. Bras. Farmacogn., 29(3): 319-324.

57. Stan, T., Teodor, E.D., Gatea, F., Chifiriuc, M.C. and Lazăr, V. (2016) Antioxidant and antifungal activity of Romanian propolis. Rom. Biotechnol. Lett., 22(6): 13116.

58. Mutlu Sariguzel, F., Berk, E., Koc, A.N., Sav, H. and Demir, G. (2016) Antifungal activity of propolis against yeasts isolated from blood culture: In vitro evaluation. $J$. Clin. Lab. Anal., 30(5): 513-516.

59. Fernández-Calderón, M.C., Hernández-González, L., Gómez-Navia, C., Blanco-Blanco, M.T., Sánchez-Silos, R., Lucio, L. and Pérez-Giraldo, C. (2021) Antifungal and anti-biofilm activity of a new Spanish extract of propolis against Candida glabrata. BMC Complement. Med. Ther., 21(1): 1-10.

60. Quiroga, E.N., Sampietro, D.A., Soberón, J.R., Sgariglia, M.A. and Vattuone, M.A. (2006) propolis from the Northwest of Argentina as a source of antifungal principles. J. Appl. Microbiol., 101(1): 103-110.

61. Papp, Z., Bouchelaghem, S., Szekeres, A., Meszéna, R., Gyöngyi, Z. and Papp, G. (2021) The scent of antifungal propolis. Sensors, 21(7): 2334.

62. Gucwa, K., Kusznierewicz, B., Milewski, S., van Dijck, P. and Szweda, P. (2018) Antifungal activity and synergism with azoles of Polish propolis. Pathogens, 7(2): 56. 